\title{
ANALISIS VALUE AT RISK DALAM PEMBENTUKAN PORTOFOLIO OPTIMAL (STUDI KASUS PERUSAHAAN PERBANKAN DI INDONESIA)
}

\author{
Yohanna Thresia Nainggolan ${ }^{1}$, Ahmad Juliana ${ }^{2}$, Citra Aziya Alantina ${ }^{3}$ \\ yohanna.thresia@gmail.comahmadjuliana75@gmail.comcitraaziya@gmail.com,
}

Fakultas Ekonomi, Universitas Borneo Tarakan

\begin{abstract}
ABSTRAK
Dalam dunia bisnis investor akan menghadapi resiko ketika investor akan berinvestasi. Oleh karena itu, untuk bahan pertimbangan bagi investor dalam berinvestasi dibutuhkan suatu perhitungan resiko.Untuk menghindari hal tersebut investor harus bisa mengantisipasi tingkat risiko dengan return yang tinggi. Untuk memperkecil resiko dan mendapatkan keuntungan yang diharapkan salah satu cara yang dapat dilakukan seorang investor adalah dengan membentuk suatu portofolio. Penelitian ini dilakukan untuk dilakukan untuk menghitung risiko dalam pembentukan portoflio optimal mernggunakan metode varians kovarians.Penelitian ini juga dilatarbelakangi masih banyaknya perbedaan pendapat dari para peneliti dan dianggap masih belum banyak penelitan yang menggunakan metode varians-kovarians pada perusahaan perbankan di Indonesia.Rumusan masalah dalam penelitian adalah bagaiman pembentukan portofolio optimal dari saham-saham perbankan di Indonesia berdasarkan metode Markowitz dan pengukuran Value at Risk pada portofolio dengan metode varians-kovarians pada harga penutupan saham-saham Perbankan di Indonesia.Keterbaharuan dalam penelitian ini adalah menggunnakan jangka waktu lama pada harga penutupan saham harian dan menggunakan metode varian kovarians dalam menanalisis Value at Risk dengan objek lebih dari dua perusahaan dalam satu portofolio.Hasil penelitian menunjukkan bahwa pada tingkat kepercayaan $95 \%$ perhitungan portofolio VaRmenunjukkan rata-rata nilai VaR0,044956. Keadaan tersebutmenunjukkan ada keyakinan 95\% bahwa kerugian yang akan ditanggung oleh investor tidak akan melebihi Rp.449,560,891.Dengan kata lain bahwa ada kemungkinan sebesar 5\% kerugian yang akan diderita investortidak akan melebihi Rp.449.560,891.
\end{abstract}

Kata-kata Kunci : Risiko Portofolio, Varians Kovarians, Value at Risk

\begin{abstract}
In the business world, almost all investments have risks. There for there is a need for a risk calculation that can be a judgment for investors in investing. To avoid that investors must be able to anticipate the level of risk with a high return. One way that an investor can do to minimize risk and get the expected benefits is to form a portfolio. There for this study was conducted to calculate the risk in the formation of an optimal portfolio using the covariance variance method.This study is also focused on the fact that the researchers still have several differences of opinion, and it is known that there is still not much study using the variance-covariance approach in Indonesian banking companies. The question
\end{abstract}


proposed in this research is how to construct an optimum portfolio of banking stocks in Indonesia based on the Markowitz method and the portfolio calculation of Value at Risk using the variance-covariance method at the closing price of banking shares in Indonesia.The novelty of this study is use a long period of time at the closing price of the daily stock and using the covariance variance method in analysis Value at Risk with objects more than two companies in one portfolio. The results shown that calculation of the $\mathrm{VaR}$ portfolio At a confidence level of $95 \%$, it produces an average $\mathrm{VaR}$ value of 0.044956. This can be defined is a confidence as much as $95 \%$ that would suffer losses that investors wo not be more than rp 449.560,891.In other words, there is a chance that Rp.449,560,891 would not surpass 5 per cent of the losses suffered by investors in portfolio.

Keywords : Portfolio Risk, Covariance Variance, Value at Risk

\section{PENDAHULUAN}

Investasi bisa diartikan sebagai salah satu cara pemodalandengan tujuan untuk menghasilkanprofittertentu sebagai hasil dari penanaman modal baik dilakukan secara langsung ataupun tidak.Didalam bisnis global, hampir semua investasi memuat ketidakpastian atau risiko (Tupan et al. 2013 : 5). Dari investasi yang telah dilakukan seorang penanam modal, ia tidak akan mengetahui secara pasti output yang akan diterimanya. Penanam modal pula menjumpai hal lain jika berinvestasi yakniapabila investor menginginkan profit yang besar maka penanam modal tersebut wajib menanggung resiko yang besar(Ismanto, 2016 :243).

Investor tidak hanya membuat investasi dalam satu aset saja, namun pada beberapa jenis aset.Gabungan aset tersebut disebut dengan portofolio. Dengan disusunnya portofolio, penanam modal berkeinginan tingkat penerimaan yang diterimanya akan maksimal dengan tingkat risiko seminimum mungkin (Ismanto, 2016 :247). Metode Markowitz ialah salah satu metode yang digunakan dalam merancang portofolio.

Risiko pada saat berinvestasi terjadi karena terdapatpergerakan dan perubahan yang tidak jelas atau tidak pasti dan tidak terlihat secara tepat. Sekarang initelah banyak dikembangkan perhitungan nilai risiko supaya penanam modal mampu mengetahui lebih awal tingkatresikonya.Bentuk perhitungan nilai resiko yang kerap digunakan ialahValue at Risk.Pengukuran dengan metodeini kerap dipakai untuk menentukan resiko kerugian maksimal yang akan diperolehinvestor pada sebuah investasi, baik investasi pada aset saham, portofolio atau obligasi(Haryanto et al. 2015 : 7886).

Menurut Tupan et al. (2013 : 6)terdapat 3 metode untuk menghitung Value at Risk yaitu metode parametrik (disebut juga metode varians-kovarians), metode simulasi historis dan metode simulasi Monte Carlo.Metode varians-kovarians menganggap bahwareturn portofolio memiliki sifat linier terhadap return aset tunggalnya dan return berdistribusi normal. Metode ini memakai matriks yang memuat elemen korelasi, bobot aset, volatilitas, 
dan kovarians. Metode simulasi historis memakai asumsi bahwa kondisi perubahan harga pasar saat ini sampai esok hari sama dengan kondisi perubahan harga pasar pada masa lalu. Metode historis pada umumnya menganggap bahwa nilai historis itu adalah kemungkinankemungkinan harga pasar yang akan terjadi pada waktu yang akan datang dengan menganggap distribusinya adalah seragam (Haryanto et al. 2015 : 7887).

Metode simulasi monte carlo ialah metode yang berguna untuk mengevaluasi suatu model deterministik yang melibatkan bilangan acak sebagai salah satu input. Metode simulasi monte carlo ini kerap digunakan jika model yang digunakan cukup kompleks, nonlinear atau melibatkan lebih dari satu pasang parameter tidak pasti. Metode ini digunakan juga untuk mengatasi prseoalan perhitungan pada suatu persoalan yang berhubungan dengan data sampling dengan distribusi peluang yang ditentukan dan diketahui dan bilangan random. Menurut Fardiansyah (2006 : 35)pengukuran resiko dengan metode Value at Risk cukup populer digunakan oleh industri keuangan di seluruh dunia saat ini. Value at Riskdianggap sebagai metode standar dalam mengukur risiko sehingga diterima dan diaplikasikan pada saat ini. Menurut Ismanto(2016 : 244) kelebihan dari Value at Risk adalah fokus pada downside risk tidak tergantung kepada asumsi distribusi dari return dan bisa diaplikasikan keseluruh produk-produk finansial yang diperdagangkan.

Penelitian Maringan, et al.(2015 : 6782)menyatakan perhitungan varian-kovarian pada saham LQ45 lebih cepat jika dibandingkan dengan menggunakan simulasi Monte Carlo. Waktu perhitungan Value at Risk dengan metode varian - kovarian adalah $3.219 \mathrm{~s}$. Sedangkan waktu simulasi Monte Carlo berbeda-beda tergantung banyaknya nilai n yang dihasilkan, semakin besar nilai nmaka akan menghasilkan waktu perhitungan yang lama. Penelitian ini juga dilatarbelakangi masih banyaknya perbedaan pendapat dari para peneliti dan dianggap masih belum banyak penelitan yang menggunakan metode varians-kovarians pada perusahaan perbankan di Indonesia.Adapun rumusan masalah dalam penelitian ini adalah bagaimanakah pembentukan portofolio optimal dari saham-saham perbankan di Indonesia berdasarkan metode Markowitz dan bagaimana pengukuran Value at Risk pada portofolio dengan metode varians-kovarians pada harga penutupan saham-saham Perbankan di Indonesia

Berdasarkan penjelasan yang telah dipaparkan sebelumnya studi ini akan menjelaskan pembentukan portofolio optimal dari saham-saham perbankan di Indonesia berdasarkan metode Markowitz dan menggunakan metode varians kovarians dalam menganalisis Value at Risk dalam portofolio optimal pada peusahaan Perbankan di Indonesia.

\section{LANDASAN TEORI DAN PENGEMBANGAN HIPOTESIS}

Investasi ialah suatu penanaman modal atau aset yang bertujuan untuk mencapai keuntungan atau laba di masa mendatang.Tingkat return atau pengembalian yang 
diharapkan dari investasi tersebut serta resikonya (risk) adalah dua aspek yang dipertimbangkan dalam keputusan investasi. Menurut Fahmi (2006) risiko merupakan ketidakpastian suatu keadaan yang timbul dengan keputusan yang ditetapkan berdasarkan pertimbangan. Hubungan antara return terhadap resiko ialah semakin besarreturn semakin besar juga resiko. Oleh sebab itu, investor harus bisa mengantisipasi tingkat risiko dengan return yang tinggi.

Tingkat pendapatan atau return ialah nilai yang ingin dicapai oleh penanam modaldalam periode tertentu dari aktivitasinvestasi pada suatu aset. Tingkat return tersebut adalah indikator untuk melihat tingkat penurunan atau kenaikan kekayaan investor dalam periode tertentu. Menurut Ismanto(2016 : 247). tingkatreturn digunakan sebagai salah satu parameter bagi penanam modaluntuk memutuskan apakah suatu investasi patut untuk dilanjutkan atau dipertahankan.

Teori portofolio didasarkan kepada kenyataan bahwa investor akan menanam modalnya ke berbagai macam jenis surat berharga yang bertujuan demi meminimalisir resiko yang akan ditanggung dan ingin mendapatkan penghasilan yang lebih besar. Menurut Jogiyanto(2014 : 7)portofolio yang dipilih investor dari sejumlah pilihan pada portofolio efisien disebut portofolio optimal dimana portofolio tersebut menawarkan resiko dan expected returnyang serasi dengan preferensi penanam modal. Diversifikasi perlu dilakukan oleh investor untuk menurunkan resiko portofolio. Diversifikasi artinya memecah dana yang dimiliki di berbagai sektor bisnis yang ada dengan penetapan presentasi dan pengkalkulasian secara cermat. Jadi yang timbul ialah investasi yang lebih teridentifikasi dari sisi resiko dan dengan sendirinya risiko yang tidak sistematis akan hilang (Fahmi, $2006: 105)$.

$V A R$ (Value at Risk) adalah metode pengukuran resiko yang cukup terkenal atau familiar. Hal itu terjadi tidak hanya karena kesederhanaan dari konsep Value at Risk sendiri tetapi juga karena mempunyai kemampuan implementasi berbagai metodologi statistika yang mutakhir dan beragam (Devi, 2010 : 22).Secara sederhananya Value at Riskhendak menrespon persoalan "seberapa banyak (sejumlah uang atau dalam persen)penanam modal dapat mengalami kerugian selama waktu investasi t dengan tingkat kepercayaan (1- $\alpha)$ ".

Kerangka berpikir penelitian ini dimulai dengan pengambilan data saham lalu berdasarkan nilai Value at Risk diambil kesimpulan.Penentuan portofolio optimal dilakukan berdasarkan metode Markowitz dari saham-saham perbankan yang terpilih. Setelah portofolio diperoleh, langkah berikutnya adalah melakukan perhitungan Value at Risk dengan metode varians-kovarians untuk mengetahui potensi kerugian yang akan dialami oleh portofolio tersebut. Selain itu,akan ditetapkanjuga besar resikonya untuk mengetahui seberapa besar saham tersebut mempengaruhi portofolio terpilih.

Penelitian ini menggunakan pengujian data return pada perusahaan Perbankan yaitu uji normalitas data saham untuk mendapatkan kesimpulan apakah data return saham berdistribusi normal atau tidak berdistribusi normal. 
Hipotesis Pertama : Uji normalitas

$\mathrm{H}_{0} \quad$ = Data return saham berdistribusi normal

$\mathrm{H}_{1} \quad=$ Data return saham tidak berdistribusi normal

\section{METODE PENELITIAN}

Data harga penutupan saham - saham perusahaan perbankan yang ada di Indonesia periode Januari 2012 - Desember 2018 ialah data sekunder yang digunakan dalam artikel ini.Data tersebut diperolehdarilaman www.finance.yahoo.com.dan data yang diperlukan adalah data sekunder historis.Populasinyaialah saham-saham perbankan di Indonesia. Teknik pengambilan sampelnya adalahsampling jenuh yaitu pengambilansemua saham perbankan yang ada di IDX30. Terdapat 5perusahaanyaitu BNI (Bank Negara Indonesia, Persero), BCA (Bank Central Asia), BRI (Bank rakyat Indonesia, Persero),BTN (Bank Tabungan Negara, Persero Tbk) sertaBank Mandiri.

Pada penelitian ini harga saham perbankan kemudian dianalisis nilai return danstandar deviasi dari tiap-tiap saham. Dengan menggunakan rumus:

$$
\mathrm{R}_{\mathrm{i}}=\frac{\mathrm{P}_{\mathrm{t}}-\mathrm{Pt}_{-1}}{\mathrm{Pt}_{-1}}
$$

Sedangkan tingkat keuntungan yang diharapkan atau expected return tiap saham individual merupakan rata-rata tertimbang realized return saham i. Rumus expected returndinyatakan secara matematis adalah sebagai berikut:

$$
\mathrm{E}(\mathrm{R})=\sum_{t=1}^{n} R_{i} p r_{i}
$$

Dimana $\mathrm{E}(\mathrm{R})$ :return harapan dari suatu sekuritas, $R_{i}$ : return ke-i yang mungkin terjadi dan $p r_{i}$ : probabilitas kejadian return ke-i. Sebelum melakukan perhitungan Value at Risk, data returnmasing-masing saham serta portofolio harus diuji terlebih dahulu. Pengujian dilakukan untuk melihat bagaimana karateristik data return setiap saham. Uji yang dilakukan ialahuji distribusi normal Kolmogorov-Smirnovpada SPSS.

Selanjutnya membuat koefisien korelasi dan kovarians. Sebelumnya telah dijelaskan bahwasanya diversifikasi akan dapat menurunkan resiko portofolio. Penurunan resiko akanefisien dan efektif jika portofolio tersebut mempunyai koefisien korelasi yang rendah. Koefisien korelasi dapat dihitung dengan persamaan: 


$$
\rho_{\mathrm{AB}}=\frac{\operatorname{Cov}\left(\mathrm{R}_{\left.\mathrm{A}, \mathrm{R}_{\mathrm{B}}\right)}\right.}{\sigma_{\mathrm{A}} \sigma_{\mathrm{B}}}
$$

Covariance adalah rata-rata antara deviasi saham i dengan j. Dalam kerangka manajemen portofolio, covariance memperlihatkanbagaimanareturndari dua sekuritas memilikitren untuk bergerak secara bersama-sama. Lalu menentukan bobot saham yang akan dimasukkan ke dalam portofolio. Untuk menetapkan jenis bobot sahammemakai bantuan solver di softwareMicrosoft excel, sehingga akan diperolehperpaduan aset yang memperlihatkan perbandingan imbal hasil resiko terbaik.

Langkah selanjutnya membuat matriks covariance saham denagn bobot porsi masing-masing saham sama.Kemudian menghitung Value at Risk dari portofolio optimal yang sudah terbentuk dengan metode Varians Kovarians dengan tingkat kepercayaan $95 \%$. Dihitung dengan rumus:

$$
\mathrm{VaR}=Z_{0,95} \cdot \sigma p \cdot \mathrm{P}
$$

dimana $Z_{0,95}=$ tingkat kepercayaan $95 \%, \sigma p=$ standar deviasi return aset portofolio.

\section{HASIL ANALISIS DAN PEMBAHASAN}

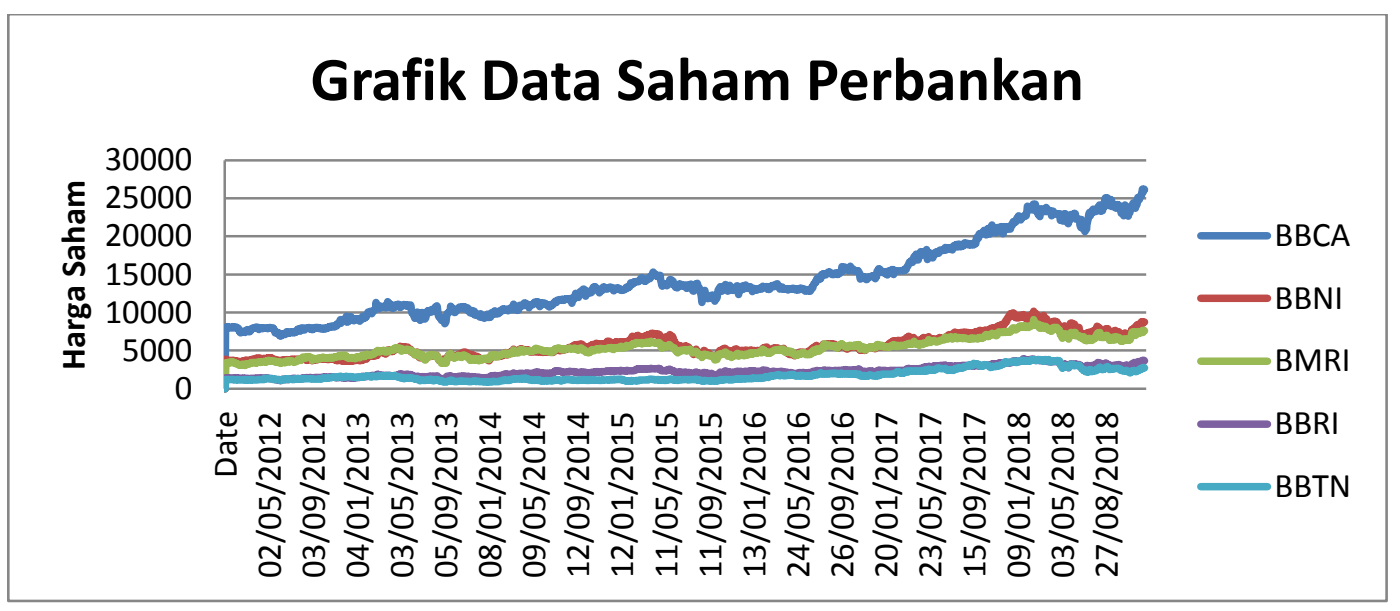

Gambar grafik harga penutupan saham perbankan

Sumber: hasil olah data (Excel)

Pada gambar diatastampakpergerakan harga saham perbankan dari tahun ketahun mengalami peningkatan danmengalami penurunan juga. Pada saham BBCA dari tahun 2012 - 2018 mengalami kenaikan yang relatif stabil. Pada saham BMRI di tahun 2013 mengalami penurunan harga saham dan kembali mengalami kenaikan pada tahun 2014 . Pergerakan harga saham yang tidak stabil di setiap tahunnya yaitu saham BBNI dan BBRI. 
Di akhir tahun 2013 harga saham perbankan pada BBTN mengalami penuruunan dari harga sebelumnya dan mengalam kenaikan pada tahun 2018.

Tabel 1 Expected Return Saham

\begin{tabular}{|c|c|c|c|}
\hline No & Kode Saham & Nama Perusahaan & E(Ri) \\
\hline 1 & BBCA & Bank Central Asia & 0,00080 \\
\hline 2 & BBNI & Bank Negara Indonesia (Persero) & 0,00068 \\
\hline 3 & BMRI & Bank Mandiri & 0,00066 \\
\hline 4 & BBRI & Bank Rakyat Indonesia (Persero) & 0,00077 \\
\hline 5 & BBTN & Bank Tabungan Negara (Persero) Tbk & 0,00077 \\
\hline
\end{tabular}

Sumber: Data diolah , 2018

Tabel 1menerangkan bahwa kelima saham mempunyai expected return bernilai positif, makadisimpulkan 5 saham tersebut mampu memberikan expected returndari portofolio. Saham berkode BBNI memliki expected return terbesar dengan nilai 0,00068 dan saham berkode BMRI memiliki expected return paling kecil dengan nilai 0,00066. Maka saham berkode BBNI membagikan expected return yang lebih besar dibandingkansaham berkode BMRI. Kemudian untuk mengetahui apakah data tersebut berdistribusi normal maka dilakukan uji normalitas terhadap return saham.

Tabel 2 One-Sample Kolmogrov-Smirnov Test

\begin{tabular}{|c|c|}
\hline Kolmogorov-Smirnov Z & Asymp. Sig. (2-tailed) \\
\hline 0,516 & 0,953 \\
\hline
\end{tabular}

Sumber: data diolah (SPSS), 2018

Tabel 2 memperlihatkan bahwa nilai K-S return saham perbankan sebesar 0,516 dan nilai tingkat signifikansi sebesar 0,953. Berdasarkan pengambilan keputusan uji normalitas dan nilai signifikansi > 0,05maka data disimpulkan berdistribusi normal.

Tabel 3 Deviasi Standar Saham

\begin{tabular}{|c|l|l|c|}
\hline No & Kode Saham & Nama Perusahaan & $\Sigma \mathrm{i}$ \\
\hline 1 & BBCA & Bank Central Asia & 0,01511 \\
\hline
\end{tabular}




\begin{tabular}{|c|l|l|l|}
\hline 2 & BBNI & Bank Negara Indonesia (Persero) & 0,01982 \\
\hline 3 & BMRI & Bank Mandiri & 0,01952 \\
\hline 4 & BBRI & Bank Rakyat Indonesia (Persero) & 0,02015 \\
\hline 5 & BBTN & Bank Tabungan Negara (Persero) Tbk & 0,02353 \\
\hline
\end{tabular}

Sumber: Data diolah , 2018

Tabel 3 mengungkapkan bahwanilai deviasi standar saham yang paling rendah jika dibandingkan dengan saham-saham bank lain dimilik oleh Bank Central Asia. Bank Central Asia memiliki nilai deviasi standar0,0151089. Nilai deviasi standar yang tertinggi apabila dibandingkan dengan sahambank lain dimiliki oleh Saham Bank Tabungan Negara. Bank Tabungan Negaramemiliki nilai deviasi standar0,0235287. Kondisitersebut membuktikanbahwaresiko paling kecil dimiliki oleh saham Bank Central Asiajika dibandingkan dengan saham Bank Tabungan Negara.

Perhitungan korelasi dalam MS.Excel menggunakan fungsi CORREL(). Jogiyanto (2014:50) langkah yang dapat digunakan dalam menghitung korelasi menggunakan CORREL() dengan cara memasukkan fungsi CORREL() dengan nilai nilai return realisasi kedalam range. Adapun hasil perhitungan nilai korelasi menggunakan fungsi CORREL() dapat diperhatikan pada tabel 4.4.

Tabel 4 Matriks Korelasi Antar Harga Saham

\begin{tabular}{|c|c|c|c|c|c|}
\cline { 2 - 6 } \multicolumn{1}{c|}{} & BBCA & BBNI & BMRI & BBRI & BBTN \\
\hline BBCA & 1 & 0,35311 & 0,50874 & 0,51167 & 0,33534 \\
\hline BBNI & 0,35311 & 1 & 0,44075 & 0,47780 & 0,27996 \\
\hline BMRI & 0,50874 & 0,44075 & 1 & 0,65753 & 0,45127 \\
\hline BBRI & 0,51167 & 0,47780 & 0,65753 & 1 & 0,453177 \\
\hline BBTN & 0,33534 & 0,27996 & 0,45127 & 0,453177 & 1 \\
\hline
\end{tabular}

Sumber: Data diolah , 2018

Pada tabel 4 dijelaskan tidak ada koefisien korelasi sebesar +1 yang mennunjukkan korelasi positif sempurna dan tidak ada koefisien korelasi sebesar -1 yang menunjukkan korelasi negatif sempurna. Semua saham memiliki nilai koefisien korelasinya diantara +1 
dan -1 yang dapat diartikan akan terjadi penurunan resiko diportofolio, tetapi tidak akan menghilangkan semua resikonya.

Dari tabel 4 dapat diketahuinilai korelasi harga antar saham yang terbesar yaitu anatara saham dengan kode BMRI dan BBRI memiliki nilai koefisien korelasi sebesar 0,6575304. Nilai korelasi harga antar saham bank yang terkecil yaitu antar saham dengan kode BBTN dan BBNI memiliki nilai koefisien korelasi0,27996409. Kondisi ini dapat memperlihatkan bahwa resiko dapat didiversifikasi atau resiko portodolio akan semakin lebih kecil apabila koefisien korelasi antar saham semakin kecil juga atau mendekati sama dengan negatif satu. Nilai korelasi koefisien antara saham berkode BBTN dan BBNI adalah saham yang mempunyai resiko portofolio paling kecil apabila dibandingkan dengan saham bank lain.

Nilai kovarian yangpositif memperlihatkan nilai dari 2 variabel bergerak berbanding lurus. Jika salah satu variabel bertambahmaka yang variabel lainnya juga bertambah atau jika salah satu variabel menurunmaka variabellainnya juga menurun. Nilai kovarian negatif menunjukkan nilai dari 2 variabel bergerak berbanding terbalik. Jika salah satu variabel bertambah, maka variabellainnya menurun atau jika satu variabel menurun maka variabel lainnya bertambah. Nilai kovarian nol memperlihatkan nilai 2 variabel independen, dimana pergerakan salah satu variabel tidak ada hubungannya dengan pergerakan variabel lainnya.

Tabel 5 Matriks Covariance Saham

\begin{tabular}{|c|c|c|c|c|c|}
\cline { 2 - 6 } \multicolumn{1}{c|}{} & BBCA & BBNI & BMRI & BBRI & BBTN \\
\hline BBCA & 0,00023 & 0,00011 & 0,000015 & 0,00016 & 0,00012 \\
\hline BBNI & 0,00011 & 0,00039 & 0,00017 & 0,00019 & 0,00013 \\
\hline BMRI & 0,00015 & 0,00017 & 0,00038 & 0,00026 & 0,00021 \\
\hline BBRI & 0,00016 & 0,00019 & 0,00026 & 0,00041 & 0,00021 \\
\hline BBTN & 0,00012 & 0,00013 & 0,00021 & 0,00021 & 0,00055 \\
\hline
\end{tabular}

Sumber: Data diolah, 2018

Dalam tabel 5dapat dilihat bahwa nilai kovarian saham berada di nilai positif, tidak ada nilai kovarian yang bernilai nol sehingga dapat dikatakan tidak ada saham yang independen yaitu pergerakan sebuah saham tidak ada hubungannya dengan pergerakan sahamlainnya. Nilai kovarian saham terbesar yaitu antara sahamyang memiliki kode BBTN dengan BBTN memiliki nilai sebesar 0,00055 dan nilai kovarian saham terkecil yaitu antara saham dengan kode BBNI dengan BBCA memiliki nilai sebesar 0,00011. 
Tabel 6 Variance Portofolio dengan Porsi saham Sama

\begin{tabular}{|c|c|c|c|c|c|c|}
\hline $\begin{array}{c}\text { Variance } \\
\text { Saham }\end{array}$ & $\begin{array}{c}\text { Porsi } \\
\text { Saham }\end{array}$ & BBCA & BBNI & BMRI & BBRI & BBTN \\
\hline BBCA & $20 \%$ & 0,000008 & 0,000004 & 0,000006 & 0,000006 & 0,000005 \\
\hline BBNI & $20 \%$ & 0,000004 & 0,000016 & 0,000007 & 0,000008 & 0,000005 \\
\hline BMRI & $20 \%$ & 0,000006 & 0,000007 & 0,000015 & 0,000010 & 0,000008 \\
\hline BBRI & $20 \%$ & 0,000006 & 0,000008 & 0,000010 & 0,000081 & 0,000009 \\
\hline BBTN & $20 \%$ & 0,000005 & 0,000005 & 0,000008 & 0,000009 & 0,00022 \\
\hline Bobot & $100 \%$ & & & & & \\
\hline \multicolumn{2}{|l|}{ Jumlah } & 0,000029 & 0,000040 & 0,000047 & 0,000114 & 0,000049 \\
\hline \multicolumn{2}{|c|}{ Expected Return Portofolio } & \multicolumn{5}{|c|}{0,000736} \\
\hline \multicolumn{2}{|c|}{ Variance Portofolio } & \multicolumn{5}{|c|}{0,000747} \\
\hline \multicolumn{2}{|c|}{ Standar deviasi Portofolio } & \multicolumn{5}{|c|}{0,027339} \\
\hline
\end{tabular}

Sumber: Data diolah, 2018

Dari tabel 6 menerangkan bahwa setiap saham dalam portofolio mempunyai porsi saham yang sama sebesar 20\% dapat meminimumkan risiko sampai 0,027339 atau 2,73\% dengan expected return yang dihasilkan sebesar 0,000736 atau 0,073\%.

Tabel 7 Perhitungan Value at Risk pada Jendela Excel

\begin{tabular}{|l|l|l|l|l|l|l|}
\hline Variabel Portofolio & BBCA & BBNI & BMRI & BBRI & BBTN & Portofolio \\
\hline Value of portofolio & & & & & & Rp10.000.000 \\
\hline Confidence level & & & & & & 0,95 \\
\hline Standar deviasi & 0,01511 & 0,01982 & 0,1952 & 0,02015 & 0,02353 & \\
\hline
\end{tabular}




\begin{tabular}{|l|l|l|l|l|l|l|}
\hline Proporsi aset & 0,2 & 0,2 & 0,2 & 0,2 & 0,2 & \\
\hline Variance portofolio & & & & & & 0,000747 \\
\hline $\begin{array}{l}\text { Std. Deviasi } \\
\text { portofolio }\end{array}$ & & & & & & 0,027331 \\
\hline No of std.Dev & & & & & & 1,645 \\
\hline Value at Risk & & & & & & 0,04496 \\
\hline Value at Risk (Rp) & & & & & & Rp.449.560 \\
\hline
\end{tabular}

Sumber: Data diolah, 2018

Pada tingkat kepercayaan 95\% diperoleh nilai Value at Risk sebesar 0,04496 apabila dana awal yang diinvestasikan pada portofolio terdiri dari 5 aset yaitu BBCA, BBNI, BMRI, BBRI, dan BBTN sebesar Rp.10.000.000. Hal ini dapat disimpulkan ada keyakinan sebesar $95 \%$ bahwa kerugian yang akan diterima investor tidak akan melebihi Rp.449.560 atau dengan kata lain ada kemungkinanbahwa 5\%kerugian investasi pada portofolio yang terdiri dari 5 saham tersebut sebesar Rp.449.560 atau lebih.

\section{PENUTUP}

\section{Simpulan}

Pembentukan portofolio optimal dari saham-saham perbankan di Indonesia berdasarkan metode Markowitz harus mempunyai expected return yang bernilai positif. Portfolio yang terbentuk terdiri dari saham-saham perbankan yaitu Bank Rakyat Indonesia, Bank Negara Indonesia, Bank Central Asia, Bank Mandiri, dan Bank Tabungan Negara. Kelima saham tersebut termasuk dalam portofolio optimal karena kelima saham tersebut memiliki nilai expected return yang positif dan tidak ada nilai expected return yang negatif.

Pengukuran Value at Risk dengan menggunakan metode varians kovarians pada harga penutupan saham-saham Perbankan di Indonesia harus memenuhi syarat yaitu data return saham harus berdistribusi normal. Kelima saham tersebut data return berditribusi normal dan perhitungan Value at Risk menggunakan standar deviasi pada portofolio dengan tingkat kepercayaan tertentu dan dana awal investasi yang telah ditentukan.

Aplikasi analisis Value at Riskdalam pembentukan portofolio yang dibahas pada penelitian ini adalah pada harga penutupan sahham harian PT Perbankan bank Central 
Asia, Bank Negara Indonesia, Bank Mandiri, bank Rakyat Indonesia (Persero) dan Bank Tabungan Negara (Persero) Tbk. Dari perhitungan analisis Value at Risk kelima saham tersebut diperoelh nilai portofolio Value at Risk sebesar 0,044956 dengan tingkat kepercayaan 95\%.Maknanyaterdapat keyakinan sebesar 95\% bahwa kerugian yang akan diterima investor pada porotoflio tidak akan melebihi Rp.449.560,891 atau dapat diartikan ada kemungkinan sebesar $5 \%$ bahwa kerugian investasi pada porotofolio sebesar Rp.449.560,891.

\section{Saran}

Berdasarkan kesimpulan yang telah dijelaskan makasaran yang disampaikan yaitu: bagi investor yang akan melaksanakan investasi di pasar modal terutama investasi pada saham yang berada di indeks IDX 30 diperlukan analisa dan perhitungan yang baik dalam menghitung expected return dan resiko portofolioo optimal. Portofolio optimal dengan menggunakan model Markowtiz memberikan tingkat resiko yang paling rendahjika dibandingkan dengan resiko indeks secara individu.

\section{Rekomendasi Penelitian Selanjutnya}

Untuk peneliti selanjutnyadapat menjadikan artikel ini sebagai rujukan atau referensipenelitian dan dapatmeneruskan pembahasan mengenaianalisis Value at Risk dengan menggunakan metode yang lain contohnyasimulasi Monte Carlo dan simulasi historis serta dapat meneliti untuk jenis perusahaan lain karena penelitian ini hanya sebatas pada perusahaan perbankan di Indonesia.

\section{DAFTAR PUSTAKA}

Budiman, Raymond. (2017). Investing is Easy Teknik Analisa dan Strategi investasi Saham untuk Pemula. Jakarta: PT Elex Media Komputindo.

Devi, Silvia Shita. (2010). Analisis Risiko Portofolio dengan Metode Varians Kovarians. Skripsi. Yogyakarta: Universitas Negeri Yogyakarta.

Fahmi, Irham. (2006). Analisis Investasi Perspektif Ekonomi dan Politik. Bandung: PT Refika Aditama.

Faizaini, I. (2012).Value at Risk Menggunakan Metode Variance Covariance. Skripsi. Surakarta: Universitas Sebelas Maret.

Fardiansyah, Teddy. (2006). Penerapan Manajemen Resiko Perbankan Indonesia. PT Elex Media Komputindo. Jakarta. 
Haryanto, A. S., Saepudin, D., dan Palupi, I. (2015). Analisis Perhitungan Value at Risk (Var) dengan Metode Historis dan Variansi-Kovariansi Serta Penerapannya dalam Portofolio. (Volume II;7886-7894)

Ismanto, Hadi. (2016). Analisis Value at Risk dalam Pembentukan Portofolio Optimal (Studi Empiris pada saham-saham yang tergabung dalam LQ45). Jurnal Ekonomi dan Bisnis. ( 243-255)

Jogiyanto. (2014). Teori dan Praktik Portofolio dengan Excel. Jakarta: Salemba Empat.

Maringga, Umbara, RF., dan Irma P. (2015). Perhitungan Value at Risk untuk Portofolio Saham dengan Metode Varian-Kovarian dan Simulasi Monte Carlo. Jurnal eProceeding of Engineering. (Volume 2; 6782-6791).

Natalia, E., Darminto, dan Endang NP. (2014). Penentuan portofolio saham yang optimal dengan model markowitz sebagai dasar penetapan investasi saham. Jurnal Administrasi Bisnis. (Volume 9; 1-9).

Sofwan, A., Rusgiono, A dan Suparti. (2014). Analisis Nilai Risiko (Value at Risk) Menggunakan Uji Kejadian Bernouli (Studi Kasus pada Indeks Harga Saham Gabungan). JournalGaussian. (Volume 3; 233-242)

Sukarno, M. (2007). Analisis Pembentukan Portofolio Optimal Saham Menggunakan Metode Single Indeks di Bursa Efek Jakarta. Tesis. Semarang: Universitas Diponegoro.

Tupan, L. P., Manurung, T., dan Prang, J. D. (2013). Pengukuran Value at Risk pada Aset Perusahaan dengan Metode Simulasi Monte Carlo. Jurnal MIPA Unsrat Online. (511). 